\title{
Building a COMMUNITY OF PRACTICE to Support Young Adults with Serious Mental Health Conditions
}

The Transitions Research and Training Center (RTC) assisted in the development of a Community of Practice (CoP) on supporting Transition Age Youth and Young Adults (TAYYA) with Serious Mental Health Conditions (SMHC). The Northeast Massachusetts Community of Practice (NE MA CoP) was composed of local stakeholders seeking to enhance services for this group.

\section{What Is a Community of Practice?}

A Community of Practice brings together "groups of people who share a concern, a set of problems, a passion about a topic, and who deepen their knowledge and expertise in this area by interacting on an ongoing basis"."

CoPs are flexible, informal groups that encourage the sharing of knowledge among members so as to advance practice. Three important characteristics distinguish a Community of Practice from other groups:

1. The domain is the focus or topic of interest. This is what the group will address in its work, and should be something that motivates the members to participate.

2. The community is built by the relationship and interaction of the members. Coming together to share similar and different experiences and problems helps create the community.

3. The practice is the common knowledge shared by the members as they seek to solve problems or create new ideas together. $^{2}$

\section{How Did We Do It?}

\section{A Community Built across the Silos:}

Transition age youth and young adults with SMHC traverse many systems and stakeholders including: child mental health, adult mental health, vocational rehabilitation, child welfare, secondary and post- secondary education, transition age youth, family members and advocates. We sought membership from all these groups.

\section{A "Champion" Made the Connections:}

In an effort to bridge the systems gap, we garnered a well-respected "Champion" ${ }^{3}$ to help bring this diverse group of stakeholders together. In this case, the champion was a regional Director of the Massachusetts Department of Mental Health Services. The Director helped us to identify and recruit local members of the NE MA CoP.

\section{A Self-Defined Goal and Self-Governing CoP:}

The CoP self-selected their leader and then their goal. The shared goal of the NE MA CoP was to create tip sheets that would provide valuable information and guidance to TAYYA with SMHC and their supporters.

\section{Infused the Voice of Youth and Young Adults with SMHC:}

All tip sheets were brought for review to a statewide young adult council, in which all members have lived experience of having a SMHC. The council provided valuable input and feedback on drafts. In turn, the young adults awarded their "Stamp of Approval" to all the CoP tip sheets.

\section{Organizational Sponsor Assisted the CoP:}

The Transitions RTC provided the NE MA CoP resources such as: website development and online meeting technology and instructions, product template and logo design, dissemination, and administrative duties i.e., note taking, posting meeting minutes, sending meeting invites and reminders. 


\section{NE MA Community of Practice Results}

The six tip sheets created are very successful and continue to be disseminated both locally and nationally by the NE MA CoP members and the Transitions RTC. They have been downloaded thousands of times from the RTC's website and linked to various organizations.

Tip Sheet Products
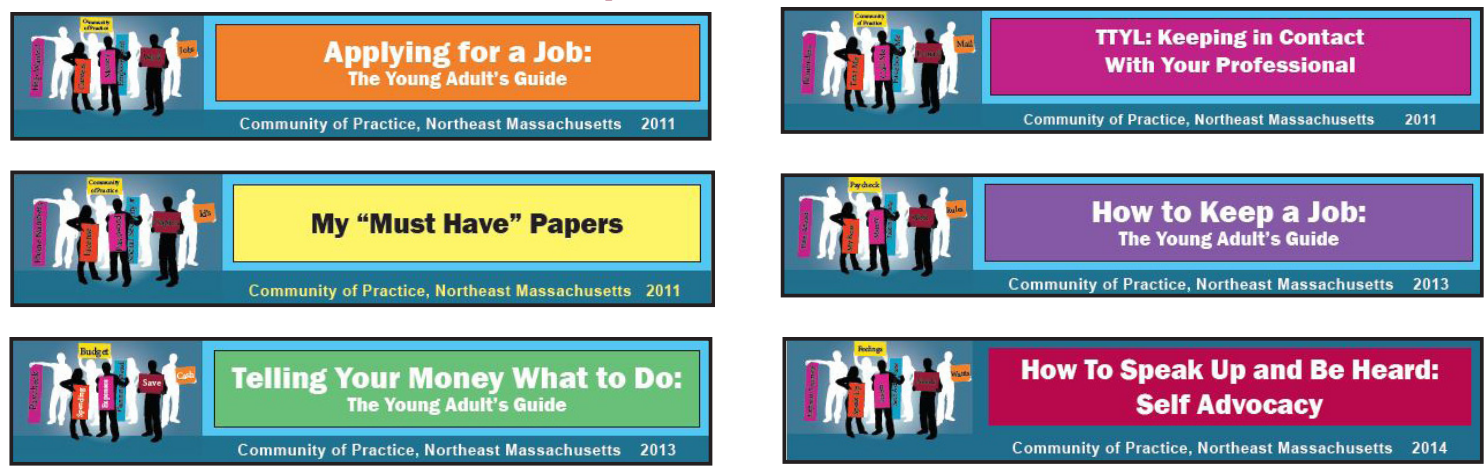

Tip Sheets available at: http://www.umassmed.edu/transitionsRTC/publication

\section{Takeaways on How to Start Your CoP}

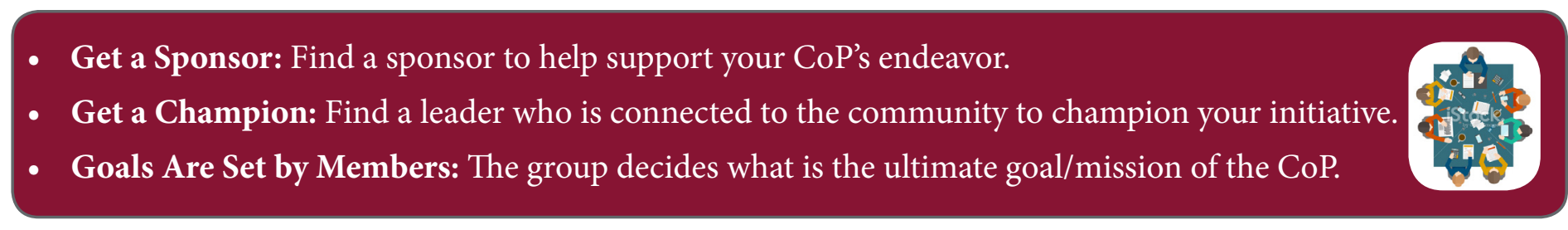

\section{Resources for CoP Models}

- Need help creating your own Community of Practice? The Transitions RTC provides Technical Assistance:

http://www.umassmed.edu/TransitionsRTC/need-help/technical-assistance-information-request/

- Cultivating Communities of Practice: A Guide to Managing Knowledge - Seven Principles for Cultivating Communities of Practice (3/25/02)

http://hbswk.hbs.edu/archive/2855.html

- Wenger, E. (2006). Communities of practice: A brief introduction. Available from http://wenger-trayner.com/theory/

- Community of Practice Design Guide: A Step-by-Step Guide for Designing \& Cultivating Communities of Practice in Higher Education (EDUCAUSE, n.d.) http://net.educause.edu/ir/library/pdf/NLI0531.pdf

- Knowing in Community: 10 Critical Success Factors in Building Communities of Practice (2001, Richard McDermott, PhD) http://www.co-i-l.com/coil/knowledge-garden/cop/knowing.shtml

- $\quad$ Network Notes III Communities of Practice (Canadian Health Services Research Foundation, n.d.):

http://www.chsrf.ca/Libraries/Network_Notes_ENGLISH/Network_Notes_III_\%e2\%80\%93_Communities_of_Practice.sflb.ashx

- Gotto, G. S., Turnbull, A., Summers, J. A., Blue-Banning, M. (2008). Community of Practice Development Manual: A Step-by-Step Guide for Designing \& Cultivating Communities of Practice. Austin, TX: SEDL. http://www.ktdrr.org/resources/rush/copmanual/CoP_Manual.pdf

- NCDDR. (2005). Communities of Practice: A Strategy for Sharing and Building Knowledge. FOCUS: Technical Brief Number 11. Austin, TX: SEDL. http://www.ktdrr.org/ktlibrary/articles_pubs/ncddrwork/focus/focus11/Focus11.pdf

\section{References}

1. Wenger, E., McDermott, R., \& Snyder, W. M. (2002). Cultivating communities of practice: A guide to managing knowledge. Boston: Harvard Business School Press. Wenger, E. (1998). Communities of practice: Learning, meaning, and identity. New York: Cambridge University Press.

Dowling, Paul. (posted Dec. 2011) ACT KM Forum: Building a Community of Practice: Learning from our own experience, Retrieved on September 16, 2014 From: http://www.docstoc.com/docs/108907403/Building-a-Community-of-Practice

University of

Massachusetts

UMASS. Medical Schoo

Systems and Psychosocial

SPARC

\section{Visit Transitions RTC online at www.umassmed.edu/transitionsRTC}

Suggested Citation: Smith, L. M., Broughton, A., Starks, J. \& Ellison, M. (2015). Building a Community of Practice to Support Young Adults with Serious Mental Health Conditions, Tip Sheet 9. Worcester, MA: University of Massachusetts Medical School, Department of Psychiatry, Systems and Psychosocial Advances Research Center (SPARC), Transitions Research and Training Center.

This publication can be made available in alternative formats upon request through TransitionsRTC@umassmed.edu NIDILRR

The contents of this tip sheet were developed with funding from the US Department of Education, National Institute on Disability and Rehabilitation Research, and the Center for Mental Health Services, Substance Abuse and Mental Health Services Administration (NIDRR grant H133B090018). Additional funding provided by UMass Medical School's Commonwealth Medicine division. The content of this tip sheet does not necessarily reflect the views of the funding agencies and you should not assume endorsement by the Federal Government. 